\title{
SUMBANGAN BERMAKNA PONDOK GONTOR DAN MASA DEPAN INDONESIA
}

\author{
H. Haikal \\ Fakultas Ilmu Sosial, Universitas Negeri Yogyakarta \\ Email: h_haikal2005@yahoo.com
}

\section{Abstract}

Based on this unfavourable condition the Trimurti of KH. Ahmad Sabal, K.H. Zainuddin Fananie, and K. H. Imam Zarkasyi strived their best to change this situation by founding Pondok Modern Gontor (PMG) and stress-ing the important of Arabic and English Languages. Almost without anything or with very limited preparation they began founding tarbiyatul atfal, preschool. Almost all of its students were local children. However, their jibad, working and studying hard after the founders and material and moral supports of its sympatbizer done step by step, PMG bas been growing slower, and later faster, especially after returning of K.H. Imam Zarkasyi finished bis study in many different places such as Sala and Sumatera Barat, or Sumbar. As the condition of PMG getting better and better, many students from many different places are coming to study at PGM which already focused on teaching students at the level junior and senior bigh schools, and then finally university.

وبناء على هذا الشرط غير المواتية تريمورتي من أستاذ أحمد ساحال، أستاذ زين الدين فنانى ، و

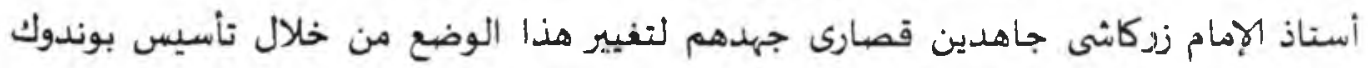

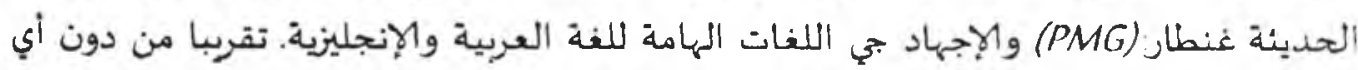

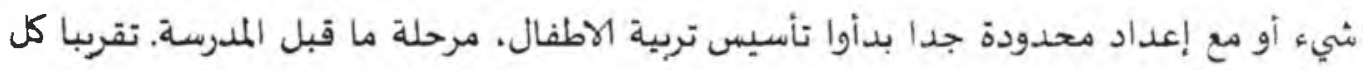

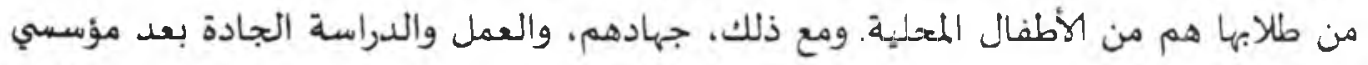

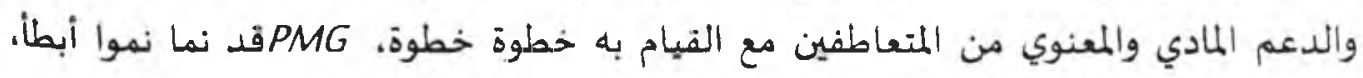
وبعد ذلك أسسع، خاصة بعد عودته من أستاذ أنهى الإمام زركاشى دراسته في العديد من أماكن 


\section{مختلفة مثل سالا وسومطرة بارات. كشرط من PMG الحصول على أفضل وأفضل، والعديد من الططالكب من العديد من أماكن مختافة يأتون للدراسة في PMG التي ركزت بالفهل على تعليم الطالاب في الإعدادية مستوى والمدارس الثانوبة العليا، ثم أخيرا جامعة.}

Keynordr. Pendidikan, Ponpes, dan Pondok Gontor

\section{A. Pendahuluan}

Ia [K.H. Imam Zarkasyi] dan Kyai Sahal sependirian bahwa kebangkitan umat Islam bergantung pada pengelolaan dalam bidang pendidikan. Pendirian ini malah sudah mereka punyai sejak zaman Belanda.Itu sebabnya mereka membina pondok.Kyai Zarkasyi tentu tidak setuju dengan kebijaksanaan pemerintah yang menekankan pendidikan untuk menjadi pegawai negeri.'

"Segala investasi yang dilaksanakan pada perkembangan dan pendidikan SDM [sumber daya manusia] yang terampil tanpa kita sadari telah dihancurkan secara sistematik dan statusnya kembali seperti kemampuan bangsa Indonesia 60 tahun lalu," katanya. ${ }^{2}$

Sejak lama para cendekiawan Indonesia telah memahami peran utama pendidikan bagi kiprab bermakna bangsa Indonesia, tanpa kecuali para ulama yang menggumuli ponpes, seperti KH Hasyim Ash'ari, KH Ali Maksum, dan yang tengah dikaji saat ini kiprah para kyai di PMG, yaitu K.H. Ahmad Sahal, K.H. Zainuddin Fananie, dan K. H. Imam Zarkasyi. Suasana keprihatinan yang lama mereka alami, tampaknya tak banyak reda.Suasana keprihatinan tak hanya melanda dan memojokkan kehidupan rakyat jelata pada umumnya, tetapi telah mampu menggusur industri strategis yang bermakna. Industri strategis yang diharapkan akan mampu mengangkat martabat bangsa Indonesia. Awalnya

'Deliar Noer, "Mengenang Almarhum K.HAL. Imam Zarkasyi". Amir Hamzah Wiryosukarto ct.al., ,K.HAL Imam Zarkasyi Di Mata Umat, (Ponorogo: Gontor Press, 1996), hal. 643.

${ }^{2}$ Sambutan Mantan presiden BJ Habibie pada acara Upacara Peringatan Hari Kebangkitan Teknologi Nasional (Hakteknas) ke-17, di Gedung Sate Bandung, Jawa Barat, Jumat 10 Agustus 2012. 
industri strategis dipelopori dan terus dikembangkan B.J. Habibie. Untuk lebih jelasnya tolong dikaji kutipan berikut ini:

Ketika krisis moneter melanda negeri ini, Industri Pesawat Terbang Nusantara (IPTN) menjadi salah satu korbannya. Restrukturisasi tak hanya mengubah nama perusahaan-men-jadi PT Dirgantara Indonesia [PTDI], tetapi juga terpaksa 'mengorbankan' para tenaga ahli yang ada di dalamnya. Banyak professional yang di PHK atau mengundurkan diri. Endri Rachman-salah seorang diantaranya, lebih memilih mundur dan kemudian hijrah ke Malaysia. Mimpi pria kelahiran Bandung ini untuk terus terlibat dalam pengembangan industri pesawat tak pernah kendur.Sambil mengajar di Universiti Sains Malaysia (USM), dia me-ngembangkan pesawat tanpa awak (AUV-Unmanned Aerial Vebicle). Namanya banyak disebut media, terutama ketika UAV ciptaannya, Tamingsari, diklaim sebagai karya Malay-sia. ${ }^{3}$

Sikap dan tindakan tokoh-tokoh sejenis Endri Rachman di atas erat berkaitan dengan agama yang dipeluknya. Tokoh ini, seperti BJ Habibie, mampu tampil secara bermakna di pang-gung sejarah dunia. Apalagi kebanyakan penduduk Indonesia beragama Islam, dan sejalan dengan Firman Allah Swt, seperti tersaji dalam QS. Ali Imran [3]:110, seharusnya mereka tampil sebagai sebaik-baik umat dengan menyuruh pada yang ma'ruf (kebaikan), mencegah dari yang munkar (kejelekan), dan beriman kepada Tuhan seru sekalian alam. Atau lengkapnya tersaji dalam ayat di atas dengan terjemahannya sebagai berikut:

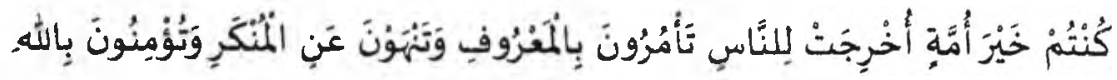

"Kamu adalah umat yang terbaik yang dilahirkan untuk manusia, menyuruh kepada yang ma 'ruf, dan mencegah dari yang munkar, dan beriman kepada Allah"

Hanya saja antar cita dengan realita, atau harapan dengan kenyataan, seringkali belum sejalan, bahkan masih ada jurang dan sebagian serba menyedihkan.Walau cukup lama bangsa ini telah mampu dan merebut kemerdekaan dengan pengorbanan harta dan nyawa.Hanya semuanya seakanakan sia-sia, tak ada artinya terutama bagi nasib rakyat jelata.Mengapa?

\footnotetext{
${ }^{3}$ Edi Santoso, "Tak Menyerah Kembangkan Industri Pesawat", Tarbawi, Edisi 272, Thal. 13, Jumadil Awwal 1433, 5 April 2012, hal. 30-1.
} 
Keadaan tetap memprihatinkan walau "... hampir tujuh dekade perjalanan bangsa ini [yang] makin jauh dari cita-cita proklamasi. Tujuan kita berbangsa dan bernegara yang telah susah payah dirumuskan para bapak bangsa, pelan tapi pasti, mulai dikhianati." A Apalagi sejak awal dalam pidato Trisaksi Bung Karno menekankan Indonesia harus tampil dan berdaulat dalam bidang politik, berdikari dalam bidang ekonomi, dan berkepribadian dalam bidang buda-ya.Dalam kenyataan yang ada membuat sebagian rakyat mengusap air mata duka.Mengapa?

Negeri yang kaya akan potensi alam tak berdaya menghadapi serbuan beragam makanan, minuman, dan aneka barang impor yang sebenarnya tumbuh serta dihasilkan di negeri sendiri. Tragis sekali, tidak hanya aneka buah, garam juga diimpor. Dalam kaitan ini menarik sajian ini:

Sejak dulu, praktik impor beras, gula, kedelai, dan terakhir daging sapi hampir semuanya berujung pada terkuaknya kasus korupsi, penyuapan, kartelitasi, dan lain-lain.

Celakanya, kasus-kasus tersebut sering melibatkan orang-orang penting di negeri ini. Ter-bongkarnya kasus dugaan suap impor daging sapi yang mengakibatkan seorang petinggi parpol ditahan Komisi Pemberantasan korupsi (KPK) belum lama ini mestinya kembali membuka mata kita bahwa ada yang tidak beres dengan kebijakan impor pangan di Indonesia. ${ }^{5}$

Kenyataan yang ada ini tampaknya berlaku juga pada yang lain, termasuk yang berkait dengan perangkat keras. Contoh mudahnya PT Kereta Api Indonesia (KAI) memilih membeli gerbong bekas kereta api Jepang. Aneh sekali, mengapa KAI tidak membeli gerbong kereta api baru buatan PT Industri Kereta Api Indonesia (Inkai). Suatu prestasi Inkai yang harus dihargai, bukan diabaikan, dengan dibeli hasilnya. Alasannya. "Kita tidak mampu kalau bayar KRL buat-an Inka yang harganya delapan kali [dibandingkan harga gerbong bekas kereta api Jepang]. Kalau tiket naik Rp. 1.000 - Rp 2.000 saja sulit apalagi naik delapan kali," ungkap Direktur Pemasaran KAI, Sulistyo Limbo." Sajian Direktur Pemasaran KAI, Sulistyo Limbo masih dapat

\footnotetext{
4"Membumikan Pemikiran Bung Karno", Editorial Media Indonesia, 17 Sept 2012, hal .1.

"Proyek Impor", Editorial Media Indonesia, Kamis 7 Februari 2013, hal. 1.

"PT KAI Memilih Kereta Bekas Jepang", Media Indonesia, Senin 22 Okt. 2012, hal. 6.
} 
dipertanyakan kebenarannya. Membandingkan murahnya harga barang bekas dengan hasil industri yang baru yang tentunya lebih mahal. Yang lebih penting lagi adalah tidak ada kebanggaan hasil produksi sendiri erat berkait dengan rasa nasionalisme yang mulai luntur, bahkan terkikis hilang. Mereka membiarkan kekayaan negeri ini diangkut ke negeri lain, tidak hanya masalah Freeport dan Busang, tetapi juga yang lain karena umumnya yang berkuasa dengan mudah "dibeli" dan menjadi pribadi kaya serta membiarkan rakyat kebanyakan sama menderita, seperti tersaji dalam kutipan berikut ini.

Indonesia pada 1970-an adalah Indonesia yang dimanjakan petrodolar, ketika Pertamina yang seharusnya milik Republik itu praktis jadi kerajaan pribadi Letnan Jenderal Ibnu Sutowo dan keluarganya, ketika kekayaan para pejabat perusahaan itu berkilau-kilau, tersimpan hingga di sudut-sudut yang jauh di luar negeri, ketika korupsi dan kemewahan membludak seperti tak akan berakhir-dan mungkin memang belum berakhir. Kejiwaan yang dibentuk oleh uang yang licin, berkilau, dan melimpah dari barel demi barel itulah yang merupakan awal jalan sesat Indonesia.?

\section{B. Pendidikan dan Kehidupan Berkeadaban ${ }^{8}$}

Kehidupan masyarakat dan warganya cukup berarti bila mereka secara bersama, atau pribadi, mampu meraih beragam prestasi.Mereka benar-benar tak berarti walaupun dianugerahi kekayaan alam dan SDM yang melimpah apabila mengabaikan pendidikan.Mereka tak mampu banyak berperan dalam kancah pergumulan dunia apabila mereka sakit dan lebih-lebih lagi tidak terjamin keamanan dalam negeri, walau mereka dikenal berilmu dan kaya raya. Jelaslah kiprah bangsa baik secara pribadi dan bersama akan benar-benar berarti dalam meraih prestasi bila ada keamanan serta kesehatan, dan sumber utama semua ini adalah pendidikan yang benar-benar diopeni, diperhatikan secara utuh dan menyeluruh. Sayangnya dalam bidang keamanan, kesehat-an, apalagi pendidikan di Indonesia terabaikan sehingya bangsa ini tak mempunyai masa depan yang menggembirakan. Untuk lebih jelasnya silahkan dikaji dan dihayati kalimat berikut ini:

'Goenawan Mohamad, "BBM", Tempo, 15 Juni 2008, hal. 154.

"Sajian yang cukup bermakna dan rinci telah disajikan beragam cendekiawan dengan tema "Agama dan Keadaban Publik", dalam Millab, Vol. XI, No. 2, Februari 2012. 
Dunia pendidikan sudah menjadi bagian yang "inheren" dari mekanisme politik, birokrasi, dan mobilisasi. Bersekolah bukanlah mencari ilmu (sekedar menghapalkan pengetahuan tertentu), bukanlah mengolah kreativitas (bahkan guru acapkali merupakan agen dekrea-tivitas), dan bukan pula menggali dan mengembangkan kepribadian (bersekolah ialah penye-ragaman atau penghapusan unikum manusia).$^{9}$

Kenyataan kiprab pendidikan yang memprihatinkan dan cukup lama berlaku di Indonesia, berbeda dengan pendidikan yang cukup bermutu di berbagai negara lain, seperti pendidikan yang lama telah berjalan di Amerika Serikat (AS). Hanya apa yang telah dicapai AS, tidak dapat dii-kuti secara membabi buta, tetapi harus diselaraskan dengan budaya setempat. Dengan pendidik-an yang bermakna telah melahirkan aneka tokoh yang berguna, salah satunya tokoh seperti John F. Kennedy.Dialah satu-satunya presiden AS yang beragama Katholik, dengan warga masyarakat yang memegang teguh budaya White Anglo Saxon Protestant (WASP). Umumnya warga dan cendekiawan AS cenderung 'meminggirkan' Katholik, apalagi yang beragama Buddha, Hindu, dan lebih-lebih lagi Islam. Siapakah Presiden John F. Kennedy?

Tokoh ini lahir di Brookline, Massachusetts, pada 29 Mei1917 dan wafat di Dallas, Texas, AS, tepatnya pada 22 November1963 saat baru berusia 46 tahun. Dia sering disebut John F. Kennedy, Kennedy, John Kennedy, Jack Kennedy, atau JFK, dan dikenal sebagai presiden AS yang ke-35.Pada 1960, dia menjadi tokoh termuda yang dipilih menjadi presiden A.S, dan termuda kedua setelah Theodore Roosevelt sebagai presiden. Kennedy menjadi presiden sctelah dilantik pada 20 Januari1961. Jabatan presiden terhenti setelah dia dibunuh oleh terjangan peluru saat melakukan kunjungan ke Dallas (Texas) pada 22 November 1963.Kennedy toboh saat mobil terbuka yang membawanya melintas di kerumunan orang yang menyambut kunjungannya.Pada 25 November1963, jenazahnya dimakamkan di Arlington, Washington, District Columbia. AS benar-benar berduka cita terbukti lebih dari 800.000 orang ikut berkabung dengan sama berdiri memberi hormat saat iring-iringan mobil jenazah melewati aneka jalan yang tersebar di Washington. Lebih memprihatinkan lagi, tampak ada upaya untuk 'menutupi' tragedi yang telah 
mengejutkan dunia ini.Terbukti sampai saat ini pembunuhan presiden ini masih menjadi semacam misteri, seakan belum ada upaya serius mengungkapkan.

Yang lebih utama lagi kalimat bersayap john F. Kennedy saat berpidato yang menyentuh hati para pendengarnya. Kalimat bersayap ini biasa dikutip banyak orang, termasuk para cende-kiawan. Mengapa? Kalımat tadi menunjukkan pentingnya pengabdian warga tanpa henti bagi suatu negeri. Presiden John Fitzgerald Kennedy dengan lantang meriyatakan: "Ask not what America can do for you, but ask what you can do for America." Lebih utama lagi keluarga Kennedy benar-benar mengutamakan pendidikan, untuk lebih jelasnya tolong dikaji dua kalimat berikut: "Pendidikan adalah nilai paling penting di rumah kami saat kami tumbuh dewasa. Orang tidak selalu menyadari bahwa orang tua kami berbagi rasa keingintahuan intelektual, [dengan] cinta membaca, dan cinta sejarah." ${ }^{10}$ Kenyataan ini berbeda sekali dengan suasana pendidikan di Indonesia, tidak saja diabaikan, tapi dianak tirikan cinta membaca, dan cinta sejarah. Bagaimana kiprab dan makna pendidikan setelah lebih dari 60 tahun Indonesia merdeka?

Tampaknya yang berkuasa di dunia pendidikan Indonesia asyik dengan beragam kegiatan perbaikan berkait dengan sisi-sisi luar pendidikan, bukan membenahi masalah pokok penyebab makin redup pendidikan. Hampir tak ada upaya sungguh-sungguh mencari penyebab utama dan bagaimana berupaya segera menanggulanginya. Salah satunya tersaji dalam berita berikut ini:

Honor Tak Dibayar, 10 Guru Jadi TKW Gunakan Kapal Menuju Tawau

Senin, 28 Januari 2013 \Larantuka, Kompas - Sepuluh guru honor di Kecamatan Wotan Uluma-do, Kabupaten Flores Timur, Nusa 'T'enggara Timur, berhenti mengajar dan memilih menjadi tenaga kerja wanita secara ilegal ke Malaysia. Selama enam tahun mengajar, mere-ka tidak mendapat honor. Kesepuluh guru honor tersebut, lima orang mengajar di SD Inpres Demondei dan lima orang lagi di SD Watodei, Kecamatan Wotan Ulumado. Marlinda Deran (27), salah seorang guru honor, ketika dihubungi Minggu (27/1), mengatakan, dia bersama sembilan guru lain sudah tiba di Makassar dan sedang menunggu perjalanan lanjutan dengan kapal Sirimau ke Kabupaten Nunukan, Kalimantan Timur. "Dari Nunukan, kami tinggal menyeberang ke 'Tawau, Malaysia," kata Deran yang sebelumnya mengajar di SD Inpres Demondei, Kecamatan Wotan

10"Pada Mulanya Kata", Koran Tempo, Ahad 20 Januari 2013, hal. A21. 
Ulumado, Pulau Adonara, Kabupaten Flores Timur.Deran mengatakan, mereka terpaksa menjadi tenaga kerja wanita (TKW) ilegal karena kecewa sudah mengajar rata-rata enam tahun tetapi tak pernah mendapat honor. Ia berharap kemungkinan itulah salah satu syarat yang harus ditempuh untuk menjadi calon pegawai negeri sipil (CPNS)."

Mengapa tak upava sungguh-sungguh untuk mengatasi masalah di atas ini? Aneka upaya lebih pada perbaikan sisi-sisi luar karena beragam sebab, yang utama adanya peran dan pesan pihak luar yang belum disadari mereka yang berkuasa. Umpamanya perubahan kurikulum, seperti tersaji dari anelsa kurikulum baru, kemudian terbiasa secara tergesa-gesa ditawarkan, dan kemudian kurikulum yang masih berlaku digusur, agar kantong para pemegang wewenang makin makmur. Untuk lebih jelasnya terlihat dari beberapa contohnya: a. Pada tahun 1984 dikenalkan dan diterapkan kurikulum CBSA, cara belajar siswa aktif, b. Pada tahun 2004 dikenalkan dan diterapkan pula KBK, kurikulum berbasis kompetensi, c. Pada tahun 2006 dikenalkan dan diterapkan K'TSP, kurikulum tingkat satuan pendidikan, dan terakhir adalah Kurikulum 2013 yang telah melahirkan beragam reaksi, salah satunya terekam dalam sajian berikut:

Kurikulum 2013 amat minim dipahami guru, apalagi publik. Cuma ada waktu sekitar enam bulan untuk sosialisasi kepada sekitar 3 juta guru dengan kemampuan [mereka] yang sangat beragam.Kurikulum 2013 pun dinilai hanya fokus kepada materi ajar, sementara aspek peda-gogis atau metode pengajaran tidak tersentuh.Metode mengajar masih satu arah dari guru ke murid. Bukan mustahil Kurikulum 2013 dipaksakan karena ada dana berlimpah dalam pelaksanaannya. Sama seperti program sertifikasi guru yang telah menghabiskan ratusan trilyun rupiah, tetapi tidak mengubah kualitas guru. ${ }^{12}$

Belum usai dengan prahara Kurikulum 2013, Kementerian Pendidikan dan Kebudayaan dihadapkan dengan masalah pembubaran rintisan sekolah bertaraf internasional (RSBI) pada Januari 2013. RSBI dimulai pada tahun 2006. Sejak lama telah muncul beragam kritik, karena berbagai kekhasan RSBI. Terbukt kucuran dana yang mereka terima, selama 2008-2010 untuk SMP yang

\footnotetext{
"http://cetak.kompas.com/read/2013/01/28/03260789/honor.tak.dibavar.10.puru.iadi.t kw. diunduh pada Selasa 29 Januari 2013.

12“Kurikulum Tanpa Arah", Editorial Media Indonesia, Rabu 5 Des. 2012, hal. 1.
} 
mendapat kehormatan berlabel RSBI, diberi kucuran dana Rp. 300 juta pertahun. Belum lagi para pengelola RSBI masih diperkenankan memungut SPP dan sumbangan sukarela. Walau telah diberi beragam fasilitas melimpah dan dana yang menimbulkan irihati aneka sekolah lain, tetapi puluhan murid SMP berlabel RSBI tidak lulus ujian nasional. Wajarlah apabila salah seorang anggota Komisi Pendidikan DPR, Dedi Suandi Gumelar, meminta pemerintah meninjau kembali RSBI karena label internasional dianggap bohong. ${ }^{13}$

Aneka masalah yang menimpa RSBI, menimbulkan kecurigaan ada korupsi dalam kiprah RSBI selama ini. Seirama dengan kenyataan ini, Kemdikbud mempersilahkan Indonesia Corrupt-ion Watch (ICW), dan masyarakat melaporkan institusinya ke KPK, Menurut Direktur Jenderal Pendidikan Dasar Kemdikbud, Suyanto, laporan tentang tindak korupsi harus dibuktikan. "Tin-dak korupsi itu bukan hanya opini, tetapi juga harus dibuktikan," kata Suyanto waktu ditemui saat rapat dengan Komisi Pendidikan DPR RI, Selasa, 15 Januari 2013. Menurutnya, tidak hanya RSBI, dia juga sepakat semua korupsi di Kemdikbud dan aneka kementerian lain harus diberantas jika memang terbukti ada. ICW menilai penggunaan anggaran pemerintah untuk RSBI seusai putusan Mahkamah Konstitusi, 8 Januari 2013, sebagai tindakan korupsi. Alasannya, kata Divisi Monitoring Pelayanan Publik, Febri Hendri, tidak ada dasar hukum untuk menjalankan program tersebut.

"Ini ada potensi sebagai korupsi," kata Febri ketika ditemui di kantor Kemdikbud. Febri menuturkan, ada empat tanda adanya korupsi, yakni ada unsur pelanggaran hukum, berpotensi merugikan negara, dilakukan pegawai hegeri sipil, dan menguntungkan orang lain. Menurutnya, empat potensi itu bisa ada ketika anggaran tetap dikucurkan seusai putusan MK. Febri menga-takan, trootonya Kemdikbud untuk menjalankan RSBI pasca putusan MK adalah Eadakan melanggar hukum. Sama sekali tidak ada dasar, program ini berpotensi menimbulkan kerugian negara. Guru atau kepala sekolah pelaksana RSBI Germpakan unsur dari pegawai negeri sipil. RSBI bisa menguntungkan aneka Thihak lain, misalnya perusahaan-perusahaan yang mencetak buku RSBI, padahal Pelaksanaan RSBI sudah tidak ada.

Mustafa Silalahi, "Wassalam, RSBI", Tempo, 20 Januari 2013, hal.76-77. 
Febri Hendri dan beberapa orang tua murid mendatangi pusat informasi Kemdikbud minta data dan alamat RSBI di semua jenjang satuan pendidikan. Kedua, salinan dokumen perincian program dan APBN yang dialokasikan program ini. Jika ada anggaran dikeluarkan setelah pu-tusan MK, Febri berencana untuk mempidanakan Kemdikbud karena berpotensi korupsi. "Kami akan laporkan upaya tindak korupsi ini," kata Febri.Suyanto mengatakan, sekolah sudah tidak boleh lagi memungut biaya ke orang tua murid seusai putusan MK. Hanya yang sudah dipungut tidak bisa dikembalikan. Sedangkan dana yang sudah diberikan pemerintah sampai tahun ajaran 2012/2013 selesai, juga tidak bisa dikembalikan.

Suyanto menuturkan, putusan MK mengenai RSBI berbeda dengan BP Migas, jadi memer-lukan masa transisi, tidak bisa langsung berhenti. Suyanto menjelaskan, BP Migas berkaitan dengan kedudukan atau jabatan, sementara RSBI berurusan dengan kebijakan."Kami sudah bertanya kepada Pak Mahfud (Ketua MK). Kata beliau, masa transisi hingga tahun ajaran selesai tidak ada implikasi hukumnya," kata guru besar Universitas Negeri Yogyakarta ini. ${ }^{14}$

\section{Pondok Modern Gontor}

Tanpa ada hiruk pikuk, dengan landasan agama Islam yang kokoh, aneka ketinggalan bangsa Indonesia yang waktu itu masih dijajah harus segera dibenahi, tanpa menghitung untung dan rugi. Semua berjalan lancar karena para pendiri mengejar berkah bukan rupiah. Para kyai sama ngurus bukan nguras betapapun aneka kendala dihadapi saat pasang naik atau pasang surut yang menimpa pondok.

Resminya Pondok Modern Gontor didirikan tiga bersaudara putra Kyai Santoso Anom Besari pada 10 April 1926 di Ponorogo, Jawa Timur. Tiga bersaudara ini adalah K.H. Ahmad Sahal, K.H. Zainuddin Fananie, dan K. H. Imam Zarkasyi yang kemudian dikenal dengan istilah Trimurti. Pada masa itu pesantren ditempatkan di luar garis modernisasi, para santri oleh warga masyarakat dianggap hanya pintar soal agama tetapi buta akan pengetahuan

${ }^{14}$ http://www.tempo.co/read/news/2013/01/15/079454507/Soal-RSBI-KemendikbudSiap-Dilaporkan-ke-KPK. di-unduh Kamis 24 Januari 2013. 
umum. Trimurti kemudian menerapkan format baru dan mendirikan Pondok Gontor dengan mempertahankan sebagian tradisi pesantren salaf dan mengubah metode pengajaran pesantren yang menggunakan sistem wetonan (massal) dan sorogan (perorangan), diganti dengan sistem kelas seperti sekolah unum. Pada awalnya Pondok Gontor hanya memiliki Tarbiyatul Atbfal (setingkat taman kanak-kanak), lalu meningkat dengan didirikannya Kulliyatul Mu'alimin AlIslamiab (KMI) yang setara dengan tingkatan sekolah menengah. Pada tahun 1963 Pondok Gontor mendirikan Institut Studi Islam Darussalam (ISID). lrama pasang naik dan pasang surut PMG, seperti beragam pondok di Jawa Timur pada umumnya, secara bermakna terlukis dalam beberapa kalimat berikut:

Tradisi pesantren di Jawa Timur sungguh mempunyai bentuk tersendiri, sehingga keduduk-an pesantren sebagai sebuah sub kultur dalam kebudayaan Jawa sangat jelas. Usia tradisi pesantren pasti sama dengan usia masuknya Islam ke Indonesia, sehingga tradisi ini mempu-nyai sumber-sumber klasik yang kaya. Selain itu pesantren menjadi bagian dari mata rantai pendidikan Islam universal, sehingga selain dari sumber-sumber lokal, pesantren juga mendapat masukan dari sumber-sumber asing. ${ }^{15}$

Untuk lebih memantapkan kiprah PGM secara bermakna, terutama dalam menghadapi ane-ka tantangan yang menghadang, dikenalkan model pengelolaan yang lebih sesuai dengan syar'i.PMG dikelola Badan Wakaf yang beranggotakan tokoh-tokoh alumni pesantren dan tokoh yang peduli Islam sebagai penentu Kebijakan Pesantren. Untuk peiaksanaannya dijalankan tiga orang Pimpinan Pondok, yaitu K.H. Hasan Abdullah Sahal (Putra K.H. Ahmad Sahal). Dr. K.H. Abdullah Syukri Zarkasyi (putra K.H. Imam Zarkasyi, dan K.H. Syamsul Hadi Abdan, S.Ag. (Putra K.H. Zainuddin Fananie). Tradisi pengelolaan tiga pengasuh ini, melanjutkan pola Trimurti (Pendiri). Pola yang tetap memelihara tradisi lama, dengan terbuka menerima yang baru asalkan bermanfaat dan sejalan dengan Islam. Model yang lama tersaji dalam beberapa kalimat ini: "Kyai dalam sebuah pesantren biasanya juga sekaligus penggagas dan pendiri pesantren, sehingga wajar dalam pertumbuhannya pesantren rangat tergantung pada peran seorang kyai. Peran kyai, dengan demikian sangat

\footnotetext{
${ }^{15}$ Kuntowijoyo, Budaya dan Masyarakat, (Yogya: Tiara Wacana, 2006), hal. 56.
} 
signifikan. Kyai dianggap memiliki pengaruh secara sosial dan politik, karena memiliki ikatan primordial dengan para santri dan masyarakat sekitarnya."16

Sekalipun mempunyai kekhasan di atas, ada kekhasan lain yang juga bermakna sekali seperti berkait dengan sikap terbuka para lulusan dan penggiat pesantren. Mereka mau mengakui dan mau belajar dari aneka kelebihan yang dimiliki pihak lain serta menyadari beragam serba kekurangan sendiri. Salah satunya terekam dalam tercermin dalam kutipan berikut:

Kalau tidak seluruh kaum muslimin di negeri ini secara resmi menjadi anggota Muham-madiyah, setidak-tidaknya dampak (impact) perubahan keyakinan gerakan Muhammadiyah te-rasa cukup besar di kalangan kaum muslimin yang menjadi pengikut gerakan Islam yang lainnya (seperti NU, SI dan lain-lain). Proses saling mempengaruhi ini mengakibatkan perubahan mendasar dalam keyakinan agama semua golongan Islam di negeri kita, dan pada gilirannya juga memberikan bekasnya dalam perubahan pandangan dunia, sistim nilai dan sikap hidup golongan Islam secara keseluruhan. Tidak hanya itu, dampak "revolusi keyakinan agama" yang dilancarkan gerakan Muhammadiyah juga terasa besar dalam keseluruhan hidup bangsa, karena semua golongan (nasionalis, sosialis, komunis, agama-agama non-Islam dII) juga terkena pengaruhnya. ${ }^{17}$

Tampaknya pola ini dinilai cukup berhasil walau aneka tantangan yang ada selalu datang silih berganti, Alhamdulillah selalu dapat diatasi. Salah satu contohnya dituliskan salah scorang mantan santri yang diuntungkan beroleh pendidikan di PMG, walau awalnya sama sekali tidak menginginkannya. Seperti umumnya para remaja, dia marah dan mutung serta mogok dari segala kegiatan yang rutin.Untuk lebih mudahnya dikaji kutipan beberapa kalimat berikut: "Di tengah gelap, aku terus bertanya-tanya kenapa orang tua harus mengatur-atur anak. Di mana kemerdeka-an anak yang baru belajar punya cita-cita? Kenapa masa depan harus diatur orang tua? Aku ber-tekad melawan keinginan Ibu dengan gaya diam dan mogok di dalam kamar gelap. Keluar hanya untuk buang air dan mengambil sepiring [nasi] untuk dimakan di kamar lagi. ${ }^{18}$

${ }^{16}$ Aziz \& Choirotun Chisaan, "Pembelajaran Sejarah di Pesantren", BASIS, no 07-08, Tahun ke 59, 2006, hal. 35.

${ }^{17}$ Abdul Rahman Wahid, Muslim di Tengab Pergumulan, (Jakarta: Leppenas, 1983) hal . 32-33

${ }^{18}$ Ahmad Fuadi, Negen 5 Menara, (Jakarta:Gramedia, 2009), hal. 11. 
Salah satu tantangan yang lebih hebat telah dialami saat usia pondok masih remaja karena PMG baru menginjak usia belasan tahun. Pada saat meletusnya peristiwa Madiun tahun 1948 saat Muso telah menguasai daerah Karesidenan Madiun (Madiun, Ponorogo, Magetan, Pacitan, dan Ngawi) dan membunuhi banyak tokoh agama, karena saat itu TNI sudah dilumpuhkan PKI, walau untuk sementara. PMG diliburkan dan santri serta ustadhnya hijrah guna menghindar dari kejaran pasukan Muso. K.H. Ahmad Sahal (alm) selamar dalam persembunyian di sebuah Gua di pegunungan daerah Mlarak, hingga disebut sebagai Gua Ahmad Sahal.

Kegiatan Pendidikan Pesantren dilanjutkan kembali setelah keadaan normal. Para santri cukup mapan dengan beragam budaya yang ada dan ternaungi dengan suasana musyawarah dan berkeadilan. Sebagian besar kegiatan tadi terekam dalam beragam rencana PBM, aneka jenis mata pelajaran, penilaian mid semester, ulangan umum, ulangan harian, blok, dan sejenisnya. ${ }^{19}$ Hanya awan kelabu yang pernah menyelimuti PMG pada masa perang kemerdekaan atau di awal zaman revolusi, tampaknya akan berulang kembali, karena serba kekhasan paham Komunisme-Marxisme. Urituk lebih jelasnya tolong dikaji sajian berikut ini: "Sayuti Melik: "Kalau ada anak muda membaca MarxismeLeninisme, lalu dia tidak tertarik, maka dia itu bebal. Tapi kalau o-rang itu ketika sudah tua masih tertarik juga pada Marxisme-Leninisme, maka dia sangat bebal." Pak Yut talak tiga dengan komunisme."20 Aneka kebebalan yang menjebak sebagian para penguasa bangsa Indonesia telah melahirkan tragedi G30S/PKI. Hanya banyak diantara para pembaca belum berkenan bercermin pada kenyataan yang memprihatinkan ini. Yang lebih utama lagi bagaimana tragedi ini tidak terulang lagi, entah dalam pola yang sama atau pola yang agak berbeda, yang tentunya lebih sulit untuk diantisipasi, apalagi untuk ditanggulangi secara tuntas.

\footnotetext{
${ }^{19} \mathrm{C}$. . . Abdullah Ali, Pendidikan Islam Multikultural di Pesantren (Yogya : Pustaka Pelajar, 2011), hal. 338-40.

${ }^{20}$ Taufik Ismail, "Setengah Abad Membina Umat di Pekalongan", dalam Emirul Chaq AKa et. al., Pekalongan Inspirasi Indonesia, (Pekalongan: Pemda Kota Pekalongan bekerja sama lengan The Pekalongan Institute dan Kirana Pustaka Indonesia, 2008), hal. 220.
} 
Sementara peristiwa G30S/PKI yang meminta banyak korban telah menyengat para sas-trawan hingga melahirkan aneka gugatan, beragam karya sastra yang cenderung memojokkan pe-ranan mereka yang menyelamatkan para korban G30S/PKI yang sia-sia. Mereka yang berkuasa dianggap penyebab utama penderitaaan mereka yang sama lari menyelamatkan diri ke luar negeri. Sebagian yang disajikan Leila S. Chudori cukup manis dan berisi, seperti dalam Pulang. Novel yang berdasarkan kajian bermakna mencoba menampilkan riwayat aneka tokoh yang terus berjuang menjadi orang Indonesia dengan kesan visualnya yang kuat dan menyengat. ${ }^{21}$

Dalam waktu yang hampir bersamaan terbit pula novel sejenis, walau dengan aneka latar belakang, Bre Redana atau Gitanyali telah melahirkan Blues Merbabu dan 65 yang mengungkap aneka pengalamannya sendiri. Sementara Laksmi Pamuncak telah menulis $A m b a{ }^{22}$ Jelaslah sajian novel ini terasa sekali aroma sejarah, apalagi menggali pengalaman lisan dari para pelaku atau korbannya. Upaya sungguh-sungguh dari mereka seakan ada pesan nurani atau semacam kejengkelan pribadi melihat keadaan dalam negeri yang memprihatinkan. Hanya patut disadari kekhasan kajian Hilmar Farid ${ }^{23}$ ini: "Sudah jelas bahwa penulisan sejarah yang lahir dari keterangan lisan para korban sangat berbeda dari sej̧arah menurut penguasa. 'Sejarah dari bawah' ini tidak hanya menolak propaganda dan tuduhan yang memang tidak berdasar, tapi lebih jauh memberi perspektif berbeda terhadap keseluruhan masalahnya."

Tetapi terasa lebih bermakna sajian Helvy Tiana Rosa yang berani menentang arus pada zaman orde baru, apa yang dilakukannya. Apa yang telah dilakukan sastrawan putri yang berjil-bab sejak 1988? Untuk lebih jelasnya

\footnotetext{
${ }^{21}$ Bagus Takwin "Menggugah Ingatan tentang Indonesia", Tempo, 23 Deșember (2012), hal. 58-9.

${ }^{22}$ Qaris Tajudin dan Erwin Prima "Misteri yang Selalu Menarik," Tempo; 23 Desember 2012, hal. 59.

${ }^{23}$ Hilmar Farid, "Kata Pengantar" dalam Hersri Setiawan, Kidung Para Korban Dari Tutur Sepuluh Nara sumber Eks Tapol, (Yogya: Pustaka Pelajar, 2006), hal. xvii. Perlu pula dihayati secara sungguh-sungguh kalimat berikut ini: "Seperti cerita Bibit, seorang aktivis yang kemudian menjadi tukang tunjuk yang ikut mengejar, menangkap dan bahkan menyaksikan penyiksaan serta pembunuhan terhadap aktivis lainnya antara pertengahan 1966 sampai akhir 1968. Semua itu dilakukan karena tidak mau menjadi korban dan mati konyol."Saya mencari selamat." (hal. xx) C.f. Sugeng Priyadi,Metode Penelition Pendidikan Sejarah, (Yogya: Ombak, 2012), hal. 56-7.
} 
tolong dihayati kalimat-kalimat berikut: "Karya dia yang cukup monumental adalah cerita pendek Jaring-jaring Merah (April 1998). Cerpen itu dianggap berani menggambarkan Aceh ketika masih menjadi daerah operasi militer.Akibat menulis cer-pen itu, dia diancam dibunuh.Karyanya tersebut dipilih sebagai Cerpen Terbaik Majalah Sastra Horison Satu Dekade (1990-2000). ${ }^{324}$

Apakah yang disajikan itu punya bobot bermakna dan tidak memuja atau mencerca? Bagaimana pula bila coba direnungkan sajian Kuntowijoyo sebagai sejarawan dan sastrawan jempolan: "Dalam penulisan sastra, sejarah tidak saja bersifat ornamental tetapi struktural. Arti-nya, ia bukan saja hadir sebagai penghias supaya cerita menarik, tetapi ikut beroperasi secara a priori dalam seluruh pekerjaan merekonstruksi sejarah."25

Berkait dengan PMG telah ditampilkan dalam novel Negeri Lima Menara yang laris manis, dengan nilai sastra dan sejarah serta pendidikannya cukup terasa indah dan menggugah. Mudan dipahami bila novel ini berkali-kali dicetak ulang, bahkan telah dibawa ke layar lebar dan memu-kau penontonnya. Dapat dikatakan terasa sekali nilai-nilai Islam dalam Negeri Lima Menara yang langsung menampilkan kiprah Pondok Modern Gontor.

Aku ingin kuliah di UI, ITB dan terus ke Jerman seperti Pak Habibie.Kala itu aku menganggap Habibie adalah seperti profesi tersendiri.Aku ingin menjadi orang yang mengerti teori-teori ilmu modern, bukan hanya ilmu figh dan ilmu hadits. Aku ingin suaraku didengar di depan civitas akademika, atau dewan gubernur atau rapat manajer, bukan hanya ceramah di mimbar surau di kampungku. Bagaimana mungkin aku bisa menggapai berbagai cita-cita besarku ini kalau aku masuk madrasah lagi?20

Wajarlah bila makna ponpes menjadi positif tidak lagi negatif. Wajarlah lahir beragam sajian dan pujian mengenai Negeri Lima Menara sehingga A. Fuadi harus tampil dalam talkshow Kick Andy. Andy Noya, wartawan dan bost talkshow Kick Andy telah memberikan komen-tamya: "Kisah inspiratif dengan selipan humor khas pondok. Jarang ada novel yang bercerita tentang apa yang terjadi di

\footnotetext{
24“"Helvy Tiana Rosa Sastra Ubah Pengecut Jadi Pemberani", Koran Tempo, Ahad 6 Januari 2013, hal. A10.

${ }^{25}$ Kuntowijoyo, Budaya dan Masyarakat, hal. 177.

${ }^{26}$ Ahmad Fuadi, Negeri 5 Menara, hal. 8-9.
} 
balik sebuah pondok yang penuh teka-teki. Buku ini sarat dengan vitamin bagi jiwa kita." Salah satunya terlukis dalam kutipan berikut ini: “. . . Pak Etek ${ }^{27}$ punya banyak teman di Mesir yang lulusan Pondok Madani di Jawa Timur.Mereka pintar-pintar, bahasa Inggris dan bahasa Arabnya fasih. Di Madani itu mereka tinggal di asrama dan diajar disiplin un-tuk bisa bahasa asing sctiap hari. Kalau tertarik, mungkin sekolah ke sana bisa jadi pertimbangan . . ... 28

Pandangan Modern K.H. Ahmad Sahal, sebagai Pendiri tertua dari Trimurti dan kedua adiknya yaitu K.H. Zainudin Fanani, dan K.H. Imam Zarkasyi diwujudkan pula dalam menyeknlahkan putra-putrinya selain di sckolah agama (pesantren) juga di sekolah umum. Drs. H. Ali Syaifullah Sahal (alm) alumni Filsafat UGM dan sebuah Universitas di Australia, dosen di IKIP Malang; Dra. Hj. Rukayah Sahal dosen IKIP Muhammadiyah Jakarta (UMJ). Tentu menjadi bahan pemikiran anggota Badan Wakaf saat ini, untuk mewrjudkan Pesantren Gontor menjadi semacam Universitas Al Azhar di Mesir, sebuah universitas yang memiliki beragam bidang kajian (Agama serta Ilmu Kedokteran dan Teknologi) yang berbasiskan Islam.

Dalam konteks inilah pesantren disamping mempertahankan kurikulum yang berbasis agama juga melengkapinya dengan kurikulum yang menyentuh dan berhubungan erat dengan persoalan dan kebutuhan kekinian umat manusia.Sejak itulah, modifikasi dan improvisasi sistemik di tubuh pesantren mulai tampak. Upaya improvisasi dan modifikasi tidak semata karena desakan eksternal melainkan yang terpenting adalah adanya motivasi internal pesan-tren itu sendiri untuk terus berbenah mensiasati perkembangan zaman. ${ }^{29}$

Pada tahun 1994 didirikan pondok khusus putri untuk tingkat KMI dan pendidikan tinggi yang khusus menerima alumni KMI. Pondok khusus putri ini menempati tanah wakaf seluas 187 hektar. Terletak di Desa Sambirejo, Kecamatan Mantingan, Kabupaten Ngawi, Jawa Timur. Kini, pondok khusus

${ }^{27}$ Pak etek adalah adik dari ibu atau bapak.

${ }^{28} \mathrm{Ahmad}$ Fuadi, Negeri 5 Menara, hal. 12.

${ }^{29}$ Aziz \& Choirotun Chisaan Iembelajaran Sejarah di Pesantren, BASIS, No 07-08, (2010), Tahun ke 59, hal. 37, lihat pula sajian A. Mukti Ali, Beberapa Masalab Pendidikan di Indonesia, (Yogya: Nida, 1971), hal.24. 
putri memiliki lima cabang, tiga cabang berlokasi di Ngawi, satu cabang di Sulawesi Tenggara dan satu di Kediri. Sampai saat sekarang PGM setidaknya telah memiliki 17 cabang yang terdiri dari 13 kampus di seluruh Indonesia dan santri serta santriwatinya mencapai 14.273 orang. Tidak seperti pesantren pada umumnya, para pendidiknya berdasi dan bercelana panjang pantalon.

Sejak awal, PMG untuk lebih memantapkan kiprah bermaknanya dengan mengenalkan Pancajiwa yang menjadi landasan pertama dan utama agar aneka kegiatan para santri tetap bermutu saat menuntut ilmu. Kegiatan bermakna mereka yang padat tetapi dibuat sedemikian rupa sehingga tetap sama menggembirakan para pesertanya, serta membuat mereka jauh dari aroma tingkah kekerasan. ${ }^{30}$ Aneka kegiatan yang mereka lakukan memberikan tiada waktu kosong. Mudahnya Pancajiwa tersaji sebagai berikut:

1. Keikhlasan

2. Kesederhanaan

3.Berdikari

4.Ukhuwah Islamiyah

5. Kebebasan

Lebih mantap lagi kiprah PMG dalam mendidik para santrinya agar sama mengetrapkan secara utuh dan menyeluruh yang menjadi motto PMG. Motto PMG makin terasa nilainya, ka-rena tidak saja dihayati tetapi selalu diamalkan dalam kegiatan sehari-hari semua pihak yang menggumuli tarbiyab atau pendidikan di PMG.Dengan menghayati, dan mengamalkan motto tersebur secara utuh serta menyeluruh, lahirlah para lulusan yang mampu tampil secara bermakna dalam masyarakat setempat, bahkan sampai di luar negeri, baik saat bekerja atau belajar. ${ }^{31}$ Lihat benar-benar sederhana tetapi bermakna motto PMG berikut ini.

\footnotetext{
${ }^{30}$ Salah satu contohnya tersaji dalam artikel Asep Purnama Bahtiar, "Kekerasan di Dunia Pendidikan". ( Koran Tempo, Jum'at 9 Nopember, 2012), hal. A 10.

${ }^{31}$ Hanya saja saat lulusan PMG berada di mancanegara, seperti orang Indonesia pada umumnya, menghadapi hal-hal sejenis ini: "Since the terrorist attacks on September 11, 2001, Islamic sthools bave often been in the spotlight of the westerm media. They are often accused of being a "breeding ground of radicalism and even terorissm" and bave evoked condemnation and fear among W'estern Countries." VValerie Sticher, "Schools Fees and Main-streaming Education : Implications of the
} 


\section{Berbudi Tinggi \\ 2. Berbadan Sehat \\ 3. Berpengetahuan Luas \\ 4. Berpikiran Bebas}

Umumnya para santri mampu berbahasa Arab dan Inggris, semua ini tidak menjadi beban bahkan peluang bagi mereka untuk meraih beragam nilai tambah. ${ }^{32}$ Sejalan dengan wahyu yang pertama kali, turun beberapa ayat dalam surat al Alaq (96): 1-5. Tanpa disadari, Roger Farr telah coba mewujudkannya dengan menekankan "Reading is the beart of education".Lima ayat inilah yang tidak saja mengilhami tapi telah diamalkan di kalangan para penggiat PMG.Semua ini sejenis jantung bagi upaya peningkatan tarbiyah bahkan ta'dib bagi siapa saja yang menggumuli dunia pendidikan.Pendidikan karakter, tarbiyah akblaqul karimah, yang utuh dan menyeluruh serta berdasar al Qur'an dan Hadits. Semua ini menyatu dalam aneka ragam mapel yang diberikan asatidh, para guru, telah melahirkan keteladanan dengan sikap penuh pengabdian dan lahirlah semacam kerinduan untuk segera mengikuti jejak bermakna asatidb. ${ }^{33}$ Bila semua ini benar-benar makin mantap di PMG dan dapat dimanfaatkan mereka yang memegang wewenang, tak akan terjadi apa yang telah menimpa industri strategis. Industri strategis yang telah berkem-bang secara mantap serta membuat pihak luar terpana, kagum, dengan karya anak bangsa Indo-nesia. Hanya saja sebagian yang berkuasa akhirnya mengikuti selera pihak asing, dan in secara tersembunyi tersaji dalam keluhan BJ Habibie berikut ini:

Ia mencontohkan PT DI yang dahulu memiliki 16.000 karyawan, sekarang tinggal 3.000 karyawan yang dalam 3 4 tahun mendatang dipensiun karena tak ada kaderisasi dalam segala tingkat. Badan Pengelola Industri Strategis (BPIS) yang mengkoordinasi 10 peru-sahaan pada tahun 1998 mempunyai kinerja turnover sekitar 10 miliar dolar AS dengan 48.000 karyawan kemudian dibubarkan, ujarnya. Industri dirgantara, kapal, kereta api, industri mesin, elektronika-komunikasi, industri senjata, dan lainnya juga tidak dapat perhatian lagi dan pembinaan,

Government's Policy of Subsidizing Islamic Boarding Schools in Indonesia”, in IJPS, Vol. 2, No. 2, 2008, Leiden University, hal. 139.

${ }^{32}$ Karel A. Steenbrink, Pesantren, Madrasah, Sekolah, a.b. Karel A. Steenbrink dan Audurrahman, Pesaniren, Madrasah, Sekolah, (Jakarta: LP3ES, 1986), hal. 180.

${ }^{33}$ C.f. Darmiyati Zuchdi, Zuhdan Kun Prasetya, dan Muhsinatun Siasah Masruri, Model Pendidikan Karakter, (Yogya: UNY Press, 2012), hal. 203-4. 
katanya."Dengan terpuruknya program pengembangan dalam negeri banyak insinyur desain memilih ke luar negeri untuk bekerja di industri pesawat terbang lain," ujarnya. ${ }^{34}$

Tampaknya langkah-langkah bermakna Habibie dengan industri strategis, secara rinci dan sistematis serta didukung aneka alasan 'ilmiah' upaya peminggirannya. Untuk lebih jelas lagi tolong dikaji salah satu alasan 'ilmiah' tadi seperti tersaji berikut ini:

However, otbers, such as Minister Habibie's airplane-and belicopter-building companies, are regarded as serious arains on the national budget, producing an item of questionable quality at a bigh cost in subsidies and, given their capital intensity, very feu' employment benefits. Market efficiencies aside, Habibie used these industries to sponsor the development of Muslim-owned enterprise, the directorship of which in usually linked to bim through ICMI. ${ }^{35}$

Penguasaan bahasa Arab sangat utama bagi memahami, menghayati, dan mengamalkan al Qur'an secara utuh dan menyeluruh dengan penuh kesungguhan. Apalagi al Qur'an penuh de-ngan aneka amtsal atau perumpamaan yang bermakna dan beraneka warna."Dengan perumpa-maan dalam al Qur'an berkaitan dengan ekosistem, ekologi, astronomi, anatomi, biologi, sosio-logi, teologi, bagi mengambil pelajaran dari kejadian masa lalu. ${ }^{36}$ Jelaslah sisi scjarah tersaji pula dalam al Qur'an, belum lagi yang berkaitan dengan segi keindahan bahasa yang tak ada tolok bandingannya. Yang terpenting lagi adalah penekanan budaya ilmu sebagai bekal kehi-dupan nyaman di dunia dan akhirat kelak, sementara salah tokoh utama PMG, telah mengama-lkan lebih dahulu. Salah satunya seperti terekam dalam sajian berikut:

Adalah di Tanah Minang ini, Kyai Zarkasyi merasa terbina perhatian, bakat, dan kecen-drungannya membangun lslam, terutama dalam bidang pendidikan. Di samping belajar dengan tekun, ia juga turut dalam organisasi pelajar. Malah ia turut mengajar beberapa waktu lamanya di Tapanuli Selatan. Untuk mendapat pengalaman. Dengan bekal demikian, ia kembali ke Gontor -

${ }^{34}$ Sambutan Mantan presiden BJ Habibie pada acara Upacara Peringatan Hari Kebangkitan Teknologi Nasional (Hakteknas) ke-17, di Gedung Sate Bandung, Jawa Barat, Jumat 10 Agustus 2012, hal. 1.

${ }^{35}$ Robert W. Hefner, Market Cultures : Society and Morality in the New Asian Capitalisms, (New York: Westview Prees, 1998), hal. 235.

${ }^{36}$ Fuad Kauma (2004), Tamsil al Qur'an, (Yogya: Mitra Pustaka, 2004), hal. 3. 
membina pondok secara modern-sehingga terkenal dengan nama Pondok Modern Gontor. Nama Darussalam dipakai juga, namun nama itu kalah tenar dari nama Pondok Modern Gontor. ${ }^{37}$

Semua ini dimungkinkan wujud antara lain karena padatnya kegiatan harian pondok yang membuat para santri makin bermutu dengan aneka gemblengan yang bermakna. Aneka tempaan ini dikenalkan bertahap bagi para santri baru, hanya kemudian menjadi kebiasaan mereka selama di PMG atau kclak setelah mereka terjun dalam kehidupan bermasyarakat. Secara mudahnya aneka kegiatan, seperti terjadi pada beragam pondok lain, terlukis dalam bcberapa kalimat ini:

Dimalam hari mereka berkumpul bersama teman sekelasnya untuk mendiskusikan materi pelajaran yang akan dibahas esok hari. Pukul sepuluh malam mercka istrirahat dan akan bangun lagi [sekitar] pukul tiga dini hari. Suasana kekeluargaan dan kesetiakawanan nyata terpancar dari balik pesantren, dari bangunan asrama dimana anak-anak itu tinggal, dari bangunan masjid dimana mereka melakukan peribadatan sehari-hari. ${ }^{38}$

Aneka kegiatan demikian beragam yang menghabiskan seluruh waktu santri, diusahakan agar tetap tidak membosankan, asalkan dihayati secara utuh dan menyejuruh.Bagi PMG ada kekhasan tersendiri karena aneka kegiatan tadi telah disajikan secara rinci dan diketahui para santri baru sejak awal. Dengan cara demikian, para santri tidak merasakan adanya beban, dan melihatnya sebagai peluang. Untuk lebih mudahnya terlihat seperti tersaji berikut ini:

0.3.30 Bangun Tidur

03.30-03.45 Persiapan Shalat Tahajud dan Shubuh

03.45-04.00 Shalat Tahajud

04.00-04.45 Mengaji Al Qur'an dan Shalat Shubuh

04.45-05.15 Muhadatsab atau Mengaji Pagi

05.15-06.30 Makan Pagi

06.39-06.55 Persiapan Masuk Kelas

06.55-08.30 Masuk Kelas

\footnotetext{
${ }^{37}$ Deliar Noer, "Mengenang Almarhum K.HAI. Imam Zarkasyi". hal. 640.

${ }^{38}$ Aziz. \& Choirotun Chisaan, Pembelajaran Sejarab di Pesantren, BASIS, No 07-08, Tahun ke 59,2010 , hal. 34 .
} 
08.30-09.00 Shalat Dhuha dan Istirahat

09.00-10.30 Masuk Kelas

10.30-10.55 Kelas

10.55-12.15 Masuk Kelas

12.15-12.30 Persiapan Shalat Dhuhur

12.30-13.00 Shalat Dhuhur

13.00-13.45 Makan Siang

13.45-14.45 Sekolah Sore

14.45-15.00 Persiapan Shalat Ashar

15.00-15.45 Shalat Ashar dan Membaca Ma'tsurat

15.45-17.00 Istirahat

17.00-18.30 Membaca Al Qur'an dan Shalat Maghrib

18.30-19.00 Agenda Ba'da Maghrib

19.00-19.30 Makan Malam

19.30-19.45 Shalat Isya'

19.45-21.30 Belajar Malam

21.30-22.00 Istirahat

22.00-03.30 Tidur

Walau demikian padat aneka kegiatan para santri, tetapi wajah gembira selalu terpancar saat mereka sama berbicara dan bercanda. Semua ini tetap muncul walau mereka berpacu dalam menyelesaikan aneka tugas dengan waktu yang sangat terbatas. Dalam kaitan ini terasa sekali pentingnya peran seni, yang juga tetap beragam pula seperti tersaji dalam sajian Gus Dur berikut:

Pada kegiatan seni suara di kalangan kaum muslimin dapat dilihat nyata hal ini. Di ling-kungan yang masih lebih dekat dengan literature keagamaan berbahasa Arab, seperti di Banten dan Jawa Timur, pagelaran dzibaiyab, berzanji dan sebagainya masih mengguna-kan bahasa Arab, disertai seni hadrah yang menetaskan [mementaskan] ode-ode berbahasa Arab itu tanpa diterjemahkan. Tetapi kita lihat di daerah Magelang yang lebih banyak terkena tradisi kultur istana dari kraton Mataram, muncul pementasan kentrung yang berisi pesan yang sama tetapi menggunakan bahasa Jawa. ${ }^{39}$

\footnotetext{
${ }^{39}$ Abdurrahman Wahid, Muslim di Tengah Pergumulan, hal. 22.
} 
Selain beragam kegiatan yang demikian bermakna, bagi para santri masih memerlukan lagi bekal bagi dirinya pribadi untuk meraih beragam prestasi di kemudian hari.Semua ini tak mung-kin dapat diraih apabila hanya dilakukan secara perorangan. Untuk itulah diperlukan aneka ragam kegiatan bersama, apalagi yang ditekankan PMG bukan sekedar mengejar output, tetapi lebih menekankan pada outcome, peran bermakna lulusan PMG setelah berkiprah dalam masyarakat. Kegiatan bermakna ini setidaknya dapat dipahami sekiranya berkenan menghayati dan mengamalkan sajian berikut ini:

Kegagalan pendidikan kita dalam mengembangkan kecerdasan sosial emosional menye-babkan anak-anak kita tak memiliki kemampuan untuk mengembangkan emosi positif dan empati, yang sangat menentukan kesejahteraan psikologis dan sosial mereka: [akibatnya mereka] mudah patah dan menyerah, mudah "galau", tak punya solidaritas sosial--padahal pertemanan merupakan sumber, bukan hanya kesuksesan, melainkan juga kebahagiaan. Kegagalan mengembangkan kecerdasan rohaniah membuat anak kita tak bahagia akibat kererasingan sumber keberadaannya sekaligus. . . . .40

Serba mengabaikan kenyataan ini dapat berakibat fatal bagi anak didik, sekalipun mercka dinyatakan mampu menjadi sarjana walau tak tahu apa-apa. Mereka tak ubahnya mesin pencari dan penyimpan Google atau Yahoo, punya segalanya seperti rumus, definisi, informasi serta sejenisnya tapi tak mampu berbuat apa-apa. Apalagi bila mereka diharapkan mampu melakukan beragam terobosan. Untuk lebih jelasnya tolong dihayati sajian berikut:

. . tak mengherankan jika para sarjana kita kerap tak bisa melakukan apa-apa, bahkan untuk dirinya sendiri. Sekolah seolah hanya bisa secara formal, membekali mercka dengan ijazah dan gelar yang kemudian, dengan selembar kertas dan gelar formal itu, ia kesana-kemari berkeliling mencari kerja dan melalui berbagai prosedur birokrasi untuk sekadar bertahan hidup dan kemudian mati tanpa kenangan, apalagi dirasa terus hidup menginspirasi masyarakat. ${ }^{41}$

Untuk mudahnya tolong dikaji aneka kegiatan khas yang harus dijalani para santri agar mampu mengikis aneka rasa sejenis iri, dengki, atau kurang

40Haidar Bagir, "Pendidikan yang Memanusiakan", Tempo, 23 Desember, 2012, hal. 108. C.f. Wiyono Agung S., "Pembelajaran yang Humanis", Kedaulatan Rakyat, Rabu 30 Januari, 2013, hal. 10.

"Husein Ja'far Al Hadar, "Humanisasi Kurikulum Pendidikan Kita", Tempo, 13 Januari, 2013, hal. A21. 
percaya diri.Berani tampil secara bermakna dalam aneka kegiatan yang nyata, dengan mengedepankan ngurus bukan nguras dalam hidup bersama.Semua harus dilath, diawali dengan diberi dorongan, dikembangkan, dan baru kemudian mereka dilepaskan untuk melatih para santri lainnya, agar semuanya makin berkembang. Untuk lebih jelasnya tolong dikaji dan dihayati sajian berikut ini.

- Selasa Pagi : Mubadatsah dan Lari Pagi

- Kamis Siang : Latihan Pidato dan Pramuka

- Kamis Malam: Latihan Pidato

- Jum'at Pagi : Muhadatsah, Lari Pagi, dan Kerja Bakti

- Ahad Malam: Latihan Pidato

Aneka kegiatan ini erat dengan sajian Ali Mustafa Yaqub berpadu segi ibadah (hubungan antar manusia dengan Allah), dan muamalah (hubungan antar sesama insan dalam kehidupan sehari-hari) serta peran akal manusia. Aturan berkait muamalah bersifat ta'aqquliatau ma'qulat al ma'no (dapat dipahami maksudnya). Sementara yang berkait dengan ibadah, biasa belum bahkan tidak dipahami para cendekiawan, apalagi kaum awam. ${ }^{42}$

Bagaimana dengan tuduhan terorisme di aneka pesantren, ada baiknya dibaca artikel John Galtung, "To End Terrorism, End State Terrorism", pada 20 September 2002, yang menunjukkan AS dan Israel sebagai Negara terror. Atau bercermin pada sajian berikut ini:

Dalam catatan Galtung, sejak tahun 1945, Amerika, baik melalui perintah langsung Pentagon untuk menyerang Negara lain atau melalui operasi CIA (Central Intelligent Agency\}, tidak kurarg dari 12 juta umat manusia telah menjadi korban, belum termasuk apa yang berlaku di Afghanistan, dan Irak.

Tidak kurang brutalnya adalah Negara terror Israel yang berupaya dengan segala cara untuk menghentikan gerakan kemerdekaan bangsa Palestina yang sudah berlangsung sejak 1948. Ajaibnya, Israel malah menuduh Palestina sebagai Negara teror, padahal apa yang mereka lakukan tidak lain dari perjuangan untuk merebut kemerdekaan yang telah diram-pas Negara Zionis itu tahun 1948 dengan dukungan Barat, terutama Amerika Serikat. ${ }^{43}$

${ }^{42}$ Ali Mustafa Yaqub, Haji Pengabdi Setan, Jakarta: Pustaka Firdaus, 2009), hal. 113-4.

${ }^{43}$ Ahmad Syafii Maarif, "Terorisme [1]", Republika, 30 Januari, 2013, hal. 12. C.f. Amir Mu'allim, "Isu Terorisme dan Stigmatisasi terhadap Pondok Pesantrren, Millah, Vol. VI, No. 1, Agustus 2006, hal. 47-60. 


\section{Penutup}

Jelaslah pendidikan bermakna telah mantap dikembangkan PMG, walau dimulai dari tingkat PAUD, arahnya telah meneropong masa depan. Pandangan ini tidak hanya diimpikan, tetapi secara bertahap diwujudkan seperti sajian K.H. Ahmad Sahal dalam dua kalimat berikut ini. "Kami ingin mendirikan Universitas, atau paling sedikit Lembaga Pendidikan Tinggi. Sebe-narnya persiapan untuk itu sudah dilakukan." ${ }^{44}$ Selain telah mantap berkembang dengan aneka fakultas, PMG juga telah mulai melangkah untuk mendirikan FK, Fakultas Kedokteran. Diawali dengan merintis pendirian rumah sakit pendidikan dan Fakultas Ilmu Kesehatan.

Semua cita-cita para pendiri ini mudah wujud karena adanya dorongan al Qur'an agar sama berlomba untuk memberi di Jalan Tuhan, dan sejalan dengan yang disenangi jiwanya. Contoh mudahnya Allah Swt membuat misal tentang orang yang menafkahkan hartanya di Jalan Allah agar beroleh balasan berlimpah scbanyak 700 kali, sejalan dengan Firman-Nya. "Perumpamaan orang-orang yang menafkahkan hartanya di jalan Allah adalah serupa dengan sebutir benih yang menumbuhkan tujuh batang, pada tiap tiap batang ada seratus butir benih, Allah melipat ganda-kan (ganjaran) bagi siapa yang Dia kehendaki.Dan Allah Maha Luas Karunia-Nya lagi Maha Mengetahui." (Lihat al-Baqarah (2): 261).

Apakah diantara para pembaca akan bersegera mengamalkan semua ini agar segala segi kehidupan lebih bermakna bagi manusia. Apabila semua ini telah wujud, tentunya umat makin bersikap tasamuh, toleran dengan munculnya aneka umat Islam yang masing-masing khas sifatnya.Keberagaman ini cukup meng-untungkan.Memudahkan apabila mereka berada di berbagai suasana dan tempat. Mudahnya seperti yang disajikan Gus Dur berikut ini: "Islam can be many different things. It can be like Permadi (a noted soothsayer), who is also a Muslim. The way I see it is that a person like Jatikusumo Cirebon was no less of a Muslim than I am. As long as someone feels be is a Muslim, that's enough, . . ." ${ }^{45}$ Untuk lebih memahami secara bermakna, seyogianya dikaji sajian Aliran Sempalan di Indonesia oleh beragam

${ }^{44}$ Deliar Noer, "Mengenang Almarhum K.HAL. Imam Zarkasyi", hal. 643.

${ }^{45}$ Harry Baskoro ed., Understanding Gus Dur, Oakarta: The Jakarta Post, 2000), hal. 141-2. 
cendekiawan dari beragam disiplin, dan cukup menarik, seperti tersaji dalam Millah. $^{46}$

Untuk lebih jelasnya ada baiknya dikaji kutipan berikut, agar bangsa ini makin bijak dengan aneka berita yang menyudutkan pondok pada umumnya: "The media, even renowned print media such as the Time magazine, The New York Times and the International Herald, sometimes create the impression that pesantren are mainly funded and idealogically influenced by the Middle East. However, many of the schools-particulary those affiliated to NU-follow a current of Islamic interpretation that finds not much support in Middle East. ${ }^{47}$ Adalah kewajiban semua pihak, terutama umat Islam, bahwa ponpes adalah masa depan bagi pendidikan yang bermutu karena semua dikelola untuk mencari berkah dan bukan mengejar rupiah. Apalagi serba kemiskinan dan kesenjangan masih menjadi serba kenyataan sehari-hari, termasuk mereka yang sama menuntut ilmu. ${ }^{48}$

Ini berkait serba warisan penjajahan Portugis, Inggris, Belanda, dan Jepang.Terutama sekali adanya sifat super pada umumnya dimiliki Belanda beserta para pengikut setianya, ter-masuk para cendekiawannya. Tanpa kecuali Snouck Hurgronje yang punya perhatian khas ter-hadap Islam serta pemeluknya, bahkan dia pernah menyatakan dirinya Muslim dan melakukan beragam penelitian berkait dengan pondok. Semuanya berjalan lancar karena ada yang menga-walnya. ${ }^{49}$ Yang menarik dia pernah mengatakan: "Pendidikan Barat adalah cara yang paling dapat dipercaya untuk mengurangi dan akhirnya

46Selanjutnya baca Millab, Vol. VII, No. 2, Februari 2008.

${ }^{47}$ Valerie Sticher, "Schools Fees and Mainstreaming Education : Implications of the Governmene's Policy of Subsi-dizing Islamic Boarding Schools in Indonesia", in IJPS; Vol. 2, No. 2, 2008, Leiden University, hal. 147

48Isjoni, Orang Melayu di Zaman yang Berubab, (Yogya: Pustaka Pelajar, 2007), hal. 146.

49،'HAL. Hasan Mustapha, asal Garut. Bertemu dengan Snouck untuk pertama kalinya di Mekah dalam tahun 1884.Ia menemani Snouck sebagai assistan selama mengunjungi pesantrenpesantren di Jawa Barat dan Jawa Tengah pada tahun 1889 dan 1890. Pada tahun 1892, atas usul Snouck ia diangkat menjadi penghulu besar di Aceh, kemudian diangkat menjadi penghulu besar di Bandung." (P. SJ. Van Koningsveld, Snouck Hurgronje dan Islam : Delapan Karangan Tentang Hidup dan Karya Seseorang Orientalis Zaman Kolonial, Oakarta: Girimukti Pasaka, 1989), hal. 225 
mengalahkan pengaruh Islam di Indonesia." Sebagai penutup baik dikaji lebih lanjut sajian alumnus PMG, sebagai berikut:

Sampai sckarang, masih banyak kepala umat Islam dibenturkan ke temboktembok dan dinding-dinding penyakit-penyakit Islamo-phobia. Karena takut pada Islam inilah, Sukarno dulu sangat menunjang ideologi yang menjadi lawannya, yaitu idelogi Marxisme-Leninisme (Komunisme), sehingga umat Islam Indonesia, paling tidak sebagian pemimpinnya, menjadi cap sasaran kontra-revolusi dan anti-Pancasila. Dan sekarang ini di zaman Orde Baru, kaum Islamo-phobia dari jurusan lain, tetapi masih menjadi ahli waris langsung Snouckisme, masih menunjukkan kegigihan untuk menghalangi perkembangan Islam . . . . 51

Jelaslah aneka label miring terhadap pondok, bukan kenyataan sebenarnya tetapi lebih pada rekayasa pihak luar atau para penguasa. Semuanya dilakukan karena ada pesan-pesan khas, untuk itu perlu ada sikap dan langkahlangkah bermakna.Semua harus dilakukan agar semua ini tidak terulang lagi dan agar Indonesia dapat tampil sebagai negara yang dihormati rakyat dan para pemimpin negara tetangga. Tetapi semua gambaran miring tentang ponpes tak berartj apabi-la dimantapkan akhlaq santri, sejalan dengan hadits berikut: "Sesungguhnya tidaklah aku diutus kecuali untuk memantapkan akhlak fumatku]." Atau dari hasil kajian, tampak sejalan dengan serba kenyataan di pondok, seperti terlukis berikut ini.

- . terdapat 5 karakter yang paling menonjol pada diri santri adalah kebersyukuran (gratitude), keadilan (faimess), kebaikan hati (kindness), kewargaan (citizenship), dan harapan (bope). Hasil penelitian ini tak jauh berbeda dengan [hasil] penelitian sebelumnya. penelitian sebelumnya menemukan bahwa [sic] 5 karakter yang paling menonjol pada bangsa Indonesia adalah kebersyukuran (gratitude), kebaikan hat (kindness), keadilan (fair-ness), kewargaan (citizenship), keadilan (faimess), dan kejujuran (integrity). Dibandingkan dengan kareakter bangsa Indonesia umumnya, karakter harapan (bope) santri lebih menonjol. 52

Serba bermakna dan ampuhnya karakter bukan saja disajikan dalam bcragam khutbah, pengajian serta sejenisnya, tetapi juga dengan gencar dikemas

50Nurcholish Madjid, Islam Kemodeman dan KeIndonesiaan, (Bandung: Mizan, 1987), hal. 194 ${ }^{51}$ Ibid., , hal. 200.

${ }^{52}$ Fuad Nashori, "Kekuaran Karakter Santri", Millah, Vol. XI, No. 1, Agustus, 2011, hal. 217. 
dalam berbagai karya, termasuk karya sastra yang populer bagi para pembacanya, seperti aneka karya J.K. Rowling, dan terutama novel terbarunya Casual Vacancy. Untuk lebih jelasnya dikaji apa yang disajikan Leila S. Chudori (2013), "Dari Hogwart ke Pagford", Tempo, 10 Februari, p. 51. Untuk lebih jelasnya menarik dibaca dihayati kutipan berikut: "The mistake ninety-nine percent of bumanity made, as far as Fats could see, was being ashamed of what they were, lying about it, trying to be somebody else. Honesty was Fats' currency, bisweapon and defense. It frightened people when you were bonest; it shocked them." ${ }^{53}$ Inilah sajian artikel dari penelitian yang berjudul Nation dan Character Building (Pengamalannya di Pondok Moderm Gontor) dengan dibantu dua teman seja-wat Miftahuddin, MHum dan Ririn Darini, MHum.

\section{DAFTAR PUSTAKA}

A.Mukti Ali. 1971. Beberapa Masalah Pendidikan di Indonesia, Yogya: Nida. Abdurrahman Wahid. 1983. Muslim di Tengah Pergumulan, Jakarta: Leppenas. "Agama dan Keadaban Publik", Millab, Vol. XI, No. 2, Februari 2012. Ahmad Syafii Maarif. 2013., "Terorisme [1]", Republika, 30 Januari. "Aliran Sempalan Agama di Indonesia", Millah, Vol. VII, No. 2, Februari 2008. Ahmad Fuadi. 2009. Negeri 5 Menara,Jakarta:Gramedia.

Ali Mustafa Yaqub. 2009. Haji Pengabdi Setan, Jakarta: Pustaka Firdaus.

Amir Mu'allim. 2006. "Isu Terorisme dan Stigmatisasi terhadap Pondok Pesantrren, Millah, Vol. VI, No. 1, Agustus.

Asep Purnama Bahtiar.2012. "Kekerasan di Dunia Pendidikan". Koran Tempo, Jum'at 9 Nopember.

Aziz\&Choirotun Chisaan. 2010. Pembelajaran Sejarah di Pesantren, BASIS, No 07-08, Th ke 59

Bagus Takwin.2012. "Menggugah Ingatan tentang Indonesia", Tempo, 23 Desember.

Darmiyati Zuchdi, Zuhdan Kun Prasetya, dan Muhsinatun Siasah Masruri .2012. Model Pendi-dikan Karakter Yogya: UNY Press.

53].K. Rowling, Casual V acangy, (London: Little Brown and Co., 2011), hal. 73. 
Deliar Noer.1996. "Mengenang Almarhum K.H. Imam Zarkasyi". Amir Hamzah Wiryosukarto et. al., K.H. Imam Zarkasyi Di Mata Umat, Ponorogo: Gontor Press.

Edi Santoso.2012. "Tak Menyerah Kembangkan Industri Pesawat", Tarbawi, Edisi 272, Th. 13, Jumadil Awwal 1433, 5 April.

Emha Ainun Nadjib.1997. Surat Kepada Kanjeng Nabi, Bandung: Mizan.

Fuad Kauma.2004. Tamsil al Qur'an, Yogya: Mitra Pustaka.

Fuad Nashori.2011. "Kekuatan Karakter Santri", Millab, Vol. XI, No. 1, Agustus.

Goenawan Mohamad .2008. "BBM", Tempo, 15 Juni.

Haidar Bagir.2012. "Pendidikan yang Memanusiakan", Tempo, 23 Desember.

Harry Baskoro ed. 2000.Understanding Gus Dur, Jakarta: The Jakarta Post.

htep://cetak.kompas.com/read/2013/01/28/03260789/honor.tak.dibayar.10.g

uru.jadi.tkw. diunduh Selasa 29 Januari 2013

http://www.tempo.co/read/news/2013/01/15/079454507/Soal-RSBI-

Kemendikbud-Siap-Dilaporkan-ke-KPK. diunduh Kamis 24 Januari 2013 Hefner, Robert W. 1998. Market Cultures: Society and Morality in the New Asian Capital-isms", New York: Westview Prees

"Helvy T'iana Rosa Sastra Ubah Pengecut Jadi Pemberani" .2013. Koran Tempo, Ahad 6 Janu-ari

Hilmar Farid, "Kata Pengantar" dalam Hersri Setiawan.2006. Kidung Para Korban Dari Tutur Sepuluh Nara sumber Eks Tapol, Yogya: Pustaka Pelajar.

Husein Ja'far Al Hadar. 2013. "Humanisasi Kurikuloum Pendidikan Kita”, Tempo, 13 Januari

Isjoni.2007. Orang Melayu di Zaman yang Berubah, Yogya: Pustaka Pelajar Koningsveld, P. SJ. Van .1989. Snouck Hurgronje dan Islam : Delapan Karangan Tentang Hidup dan Karya Seseorang Orientalis Zaman Kolonial, Jakarta: Girimukti Pasaka

Kuntowijoyo .2006. Budaya dan Masyarakat, Yogya: Tiara Wacana "Kurrikulum Tanpa Arah".2012. Editorial Media Indonesia Rabu 5 Des. Leila S. Chudori.2013. "Dari Hogwart ke Pagford", Tempo, 10 Februari "Membumikan Pemikiran Bung Karno" .2012. Editorial Media Indonesia, 17 Sept 
Mustafa Silalahi .2013. “Wassalam, RSBI”, Tempo, 20 Januari.

Nurcholish Madjid .1987. Islam Kemodeman dan KeIndonesiaan, Bandung: Mizan.

"Pada Mulanya Kata", .2013. Koran Tempo, Ahad 20 Januari.

"PT KAI Memilih Kereta Bekas Jepang".2012., Media Indonesia, Senin 22 Okt.

"Proyek Impor", Editorial Media Indonesia, Kamis 7 Februari 2013.

Qaris Tajudin dan Erwin Prima .2012., "Misteri yang Selalu Menarik," Tempo, 23

Desember.

Rowling, J.K. 2011. Casual Vacang, (London: Little Brown and Co.

Sambutan Mantan presiden BJ Habibie pada acara Upacara Peringatan Hari

Kebangkitan Teknologi Nasional (Hakteknas) ke-17 (2012), di Gedung

Sate Bandung, Jawa Barat, Jumat 10 Agustus

Steenbrink, Karel A., "Pesantren, Madrasah, Sekolah", a.b. Karel A. Steenbrink dan Abdurrah-man .1986. Pesantren, Madrasah, Sekolah, Jakarta: LP3ES

Sticher, Valerie.2008. "Schools Fees and Mainstreaming Fducation :

Implications of the Government's Policy of Subsidizing Islamic Boarding

Schools in Indonesia", in IJPS, Vol. 2, No. 2, , Leiden University

Sugeng Priyadi.2012. Metode Penelitian Pendiditean Sejarah, Yogya: Ombak

Taufik Ismail. 2008. "Setengah Abad Membina Umat di Pekalongan", dalam

Emirul Chaq AKa et. al. 2008. Pekalongan Inspirasi Indonesia, Pemda Kota

Pekalongan bekerja sama dengan The Pekalongan Institute dan Kirana

Pustaka Indonesia

Wiyono Agung S. 2013. "Pembelajaran yang Humanis", Kedaulatan Rakyat, Rabu 30 Januari

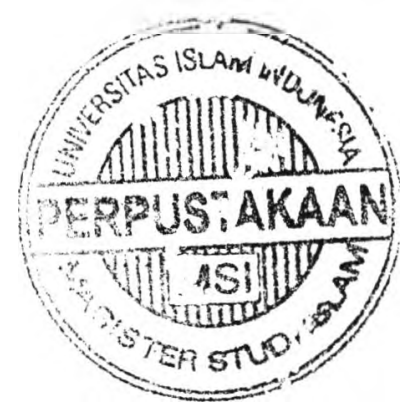

